\title{
Screening 31 endocrine-disrupting pesticides in water and surface sediment samples from Beijing Guanting reservoir
}

\author{
Nandong Xue, Xiaobai Xu *, Zuliang Jin \\ State Key Laboratory of Environmental Chemistry and Ecotoxicology, Research Center for Eco-Environmental Sciences, \\ Chinese Academy of Sciences, 18 Shuangqing Road, Beijing 100085, PR China
}

Received 21 January 2005; received in revised form 16 April 2005; accepted 18 April 2005

Available online 27 June 2005

\begin{abstract}
For screening 31 potential or suspected endocrine-disrupting pesticides in water and surface sediments, a multiresidue analysis method based on gas chromatography with electron capture detection (GC/ECD) was developed. Solid phase extraction (SPE) technology with Oasis ${ }^{\circledR}$ HLB cartridge was also applied in sample extraction. The relevant mean recoveries were $70-103 \%$ and $71-103 \%$ for water and sediment, respectively. Relative standard deviations (RSD) are $2.0-7.0 \%, 4.0-8.0 \%$ for water and sediment, respectively. Thirty one pesticides $(\alpha-\mathrm{HCH}, \beta-\mathrm{HCH}, \gamma-\mathrm{HCH}, \delta-\mathrm{HCH}$, hexachlorobenzene (HCB), aldrin, heptachlor, endosulfan I \& II, $p, p^{\prime}$-DDD, $o, p^{\prime}$-DDT, $p, p^{\prime}$-DDT, $p, p^{\prime}$-DDE, endrin aldehyde, endosulfan sulphate, methoxychlor, hepachlor epoxide, $\alpha$-chlordane, $\gamma$-chlordane, dieldrin, endrin, dicofol, acetochlor, alachlor, metolachlor, chlorpyriphos, nitrofen, trifluralin, cypermethrin, fenvalerate, deltamethrin) in water and surface sediment samples from Beijing Guanting reservoir were analyzed. Concentrations of pesticides ranged from 7.59 to $36.0 \mathrm{ng} \mathrm{g}^{-1}$ on a dry wt. basis for sediment samples, from 279.3 to $2740 \mathrm{ng}^{-1}$ for pore waters and from 48.8 to $890 \mathrm{ng}^{-1}$ for water samples, respectively, with a mean concentration of $10.7 \mathrm{ng} \mathrm{g}^{-1}$ in sediment, $735 \mathrm{ng} \mathrm{l}^{-1}$ in pore water and $295 \mathrm{ng} \mathrm{l}^{-1}$ in water, respectively. The data obtained provides information on the levels and sources of endocrine-disrupting pesticides in Guanting reservoir. These results underscore the need to improved environmental protection measures in order to reduce the exposure of the population and aquatic biota to these endocrine-disrupting compounds.
\end{abstract}

(c) 2005 Elsevier Ltd. All rights reserved.

Keywords: Solid phase extraction (SPE); Endocrine disrupting pesticides; Surface sediment; Guanting reservoir

\section{Introduction}

Endocrine disruptors are ubiquitous environmental contaminants found in a variety of products, such as pesticides, wood preservatives, paints and plastics as

\footnotetext{
* Corresponding author. Tel.: +8610 62919177; fax: +86 10 62923563.

E-mail address: xuxb@public.bta.net.cn (X. Xu).
}

well as occurring naturally in some plants. It is hypothesized that they can cause adverse effects by interfering in some way with the body's hormones or chemical messengers and may induce a broad spectrum of biochemical and toxic responses at low environmentally relevant dose (Colborn et al., 1996). Their potential health effects include reproductive disorders, cancer and impaired development (Hileman, 1994; Colborn and Smolen, 1996; Turusov et al., 2002; Zhou et al., 2004). Studies have suggested that some pesticides have been identified 
as potential or suspected endocrine disruptors. However, pesticide application safety was used to be internationally assessed by Maximum Residue Levels (MRL) based on the Acceptable Daily Intake (ADI) with a considerable safety margin. Safety assessments of pesticides do not take into account of possible endocrine disrupting properties of pesticides. Many MRLs may well be too high to exclude hormone disruption as a possible effect of being exposed to residues in food and drinking water. Studies have suggested that, unfortunately, there are no desirable methods to screen and test endocrine disruptors at present (Zhou et al., 2004). Pesticides not only can be concentrated in the environment through biogeochemical processes, but also often scavenged from the water through sorption onto suspended material and get deposited to become a part of the bottom substrate. The sediment component of aquatic ecosystems can be sunk for pesticides. Consequently, bottom sediments often become reservoirs of pesticides in the environment (Khan, 1977; Chau and Afgan, 1982). Therefore, the investigation of distribution of endocrine disrupting pesticides in water and sediment can provide a valuable record of contamination in aquatic environments (Doong et al., 2002).

Different pesticides pose varying degrees and types of risk to water quality. Some surveys of pesticide contamination in water have reported in coastal and estuarine sediments collected from Asian countries such as Vietnam, Turkey, Korea and China (Hong et al., 1999; Khim et al., 1999; Nhan et al., 1999; Doong et al., 2002; Bakan and Ariman, 2004; Zhang et al., 2004) indicating the presence of significant source of pesticides in these regions. China is the world's second largest producer of pesticides, and a pesticide production of 260000 tonnes was recorded in 1994 (Zhang et al., 2002a). Several studies have reported, despite the ban and restriction on the usage of some organochlorine pesticides (OCPs) since 1983 in China, the presence of elevated levels of OCPs, such as DDTs and HCHs, in seawater and coastal sediments (e.g. Zhou et al., 2001) and some river/estuarine systems (Hong et al., 1995; Chen et al., 1996; Wu et al., 1999; Zhou et al., 2000). Furthermore, DDT concentrations in marine mussels collected from China were still high, one to two orders of greater than those of other Asian countries (Nakata et al., 2002; Monirith et al., 2003; Li et al., 2001). These results suggest significant pollution sources of pesticides are present in China. However, most studies examined pesticides (such as OCPs) levels in waters, sediments from the marine environment (Qiu et al., 2004; Nakata et al., 2005), and up to now, in China, very little field monitoring data is available for the presence of environmental endocrine disrupting pesticide residues in freshwater. An understanding of the impacts of endocrine disrupting pesticides on China's environment is therefore very limited.
The study focuses on developing a method based on a pesticide multi-residue analysis to screen endocrine disrupting pesticides in water and sediment. Some pesticides identified as potential or suspected endocrine disruptors such as $\alpha-\mathrm{HCH}, \beta-\mathrm{HCH}, \gamma-\mathrm{HCH}, \delta-\mathrm{HCH}$, hexachlorobenzene (HCB), aldrin, heptachlor, endosulfan, $p, p^{\prime}$-DDD, $o, p^{\prime}$-DDT, endrin aldehyde, endosulfan sulphate, $p, p^{\prime}$-DDT, $p, p^{\prime}$-DDE, methoxychlor, hepachlor epoxide, chlordane, dieldrin, endrin, dicofol, acetochlor, alachlor, metolachlor, chlorpyriphos, nitrofen, trifluralin (HEPO), cypermethrin, fenverate, deltamethrin were simultaneously determined. These pesticides were selected to be screened because they have been identified as potential pollutants in food or drinking water and also been listed as endocrine disrupting chemicals by EU or by the European Commission or US EPA (Kelce et al., 1995; US EPA, 1998; Ren and Jiang, 2001) or by the Federal Environment Agency in Germany (ENDS, 1999), and because they either are widely used in the studied area for agricultural and public purposes or are present as persistent residues of previous uses. The data would be useful to local government to renew Guanting reservoir, a Beijing municipal water supply source.

\section{Materials and methods}

\subsection{Study area and sampling locations}

Guanting reservoir located in the northwest of Beijing is one of two main water resources for agriculture, industry and living uses of Beijing. Since Guanting reservoir has suffered from extensive pollution over the last decades (particularly in 1980s) due to runoff from nonpoint sources, direct dumping of waste into rivers and pollutants carried by rivers (Wang et al., 2000; Zhang et al., 2002b), Guanting reservoir has not supplied with living water for Beijing city since 1997. Particularly, the economy of the coasts of these rivers that flow in Guanting reservoir is heavily based on agriculture, thus agrochemicals are used intensively to improve crop yields, and some pesticides were used heavily in the areas in past or at present time.

The locations of the sampling sites in Guanting reservoir are shown in Fig. 1. The sites were chosen based on hotspots of pollution around Guanting reservoir such as industrial region, domestic wastewater discharge areas or entrances of rivers. Throughout the survey a global positioning system (GPS) was used to locate the sampling locations. The top sediment samples (a mixture of sediment from the upper $10 \mathrm{~cm}$ ) were collected by a grab sampler (Wildco 197c/s, Wildlife Supply Company, SAGINAW, Michigan, USA) in seven sampling sites. Samples were homogenized on site in clean glass containers. All samples were immediately sealed and stored 


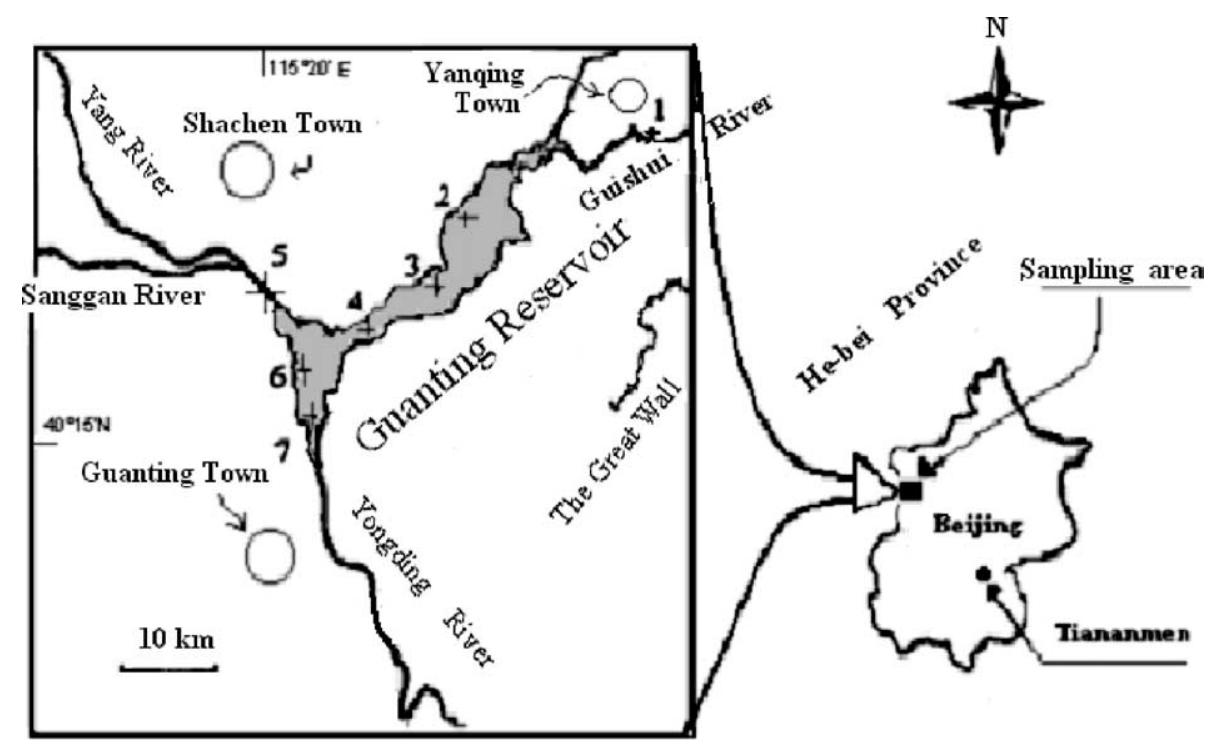

Fig. 1. Sampling sites in Guanting reservoir and its geographical location (1, 2, 3, 4, 5, 6 and 7 denote seven sampling sites in Beijing Guanting reservoir: 1, Yanqing; 2, Liushawang; 3, Erdaojian; 4, Baizhaihe; 5, Baohaoqiao; 6, Yanghekou; 7, Baqian).

at $-20^{\circ} \mathrm{C}$ in pre-cleaned glass jars until analysis. Samples were collected in September and November 2003, June and August 2004. Site descriptions have been given in Table 2 indicating the possible load of pollutants through agricultural, industrial and domestic discharges. Surface water samples were collected in the same sites. Samples were taken using pre-cleaned glass bottles held in a weighted stainless-steel frame fitted with a springloaded PTFE (polytetrafluoroethylene) stopper with a subsurface trigger to avoid sampling the surface microlayer. Aliquots of the sample were added into internal standard (IS, $0.05 \mu \mathrm{g} \mathrm{I}^{-1}$ sample) and then filtered under vacuum to remove suspended particulate matter (SPM) after returning to the laboratory within one or two days.

\subsection{Chemicals and materials}

Chromatography analysis-grade acetonitrile (ACN) and methanol (Tianjing chemical plant, China), residue analysis-grade $n$-hexane, acetone, dichloromethane (DCM) and ethyl acetate (Merck, Darmstadt, Germany) were used for sample processing and extraction. Anhydrous sodium sulfate was supplied by $\mathrm{Liu}-\mathrm{Li}$ chemical plant (Beijing, China) and treated at $140^{\circ} \mathrm{C}$ for $24 \mathrm{~h}$ before using. De-ionized water was purified with an Ultra-pure water system (Beijing Li-Yuan electronic Ltd., China). Some pesticide standards $(\alpha-\mathrm{HCH}, \beta-\mathrm{HCH}$, $\gamma-\mathrm{HCH}, \delta-\mathrm{HCH}, \mathrm{HCB}$, aldrin, heptachlor, endosulfan, $p, p^{\prime}$-DDD, $o, p^{\prime}$-DDT, endrin aldehyde, endosulfan sulphate, $p, p^{\prime}$-DDT, $p, p^{\prime}$-DDE, methoxychlor, HEPO, chlordane, dieldrin, endrin) and internal standard (IS, $2,4,5,6$-tetrachloro- $m$-xylene) used in this study from Dr. Ehrenstorfer (Augsburg, Germany) were purchased from J\&K CHEMICAL Ltd. (Table 1). Other pesticide standards (dicofol, acetochlor, alachlor, metolachlor, chlorpyriphos, nitrofen, trifluralin, cypermethrin, fenvalerate, deltamethrin) used in this study from Institute of Agricultural Environment Protection (Tianjing, China) were purchased from Yin Tian Yi stardard Ltd. (Table 1). The purity of all compounds was more than $95 \%$. Standard solutions of pesticides were prepared by dilution in acetone or alcohol and stored in freezer at $-20{ }^{\circ} \mathrm{C}$. The stock standard solution of each pesticide was of $2 \mathrm{mg}^{-1}$.

Intermediate standard solutions were prepared by dilution in acetone and subsequently dilution was made for GC analyses in the range 0.01-1.0 $\mathrm{ng}^{-1}$ Florisil (60100 mesh) from Supelco Inc. (Bellefonte, PA, USA) was used as sorbents in the clean-up columns. Florisil was activated at $130{ }^{\circ} \mathrm{C}$ for $12 \mathrm{~h}$ and partially deactivated with $0.5 \%$ water prior to use. The columns were protected against water by adding a $1-\mathrm{cm}$ layer of anhydrous sodium sulfate on top of the sorbent. The Oasis ${ }^{\circledR}$ HLB cartridge $(6 \mathrm{cc}, 500 \mathrm{mg})$ was purchased from Waters Corp. (Milford, MASS, USA) and Visiprep $^{\mathrm{TM}}$-DL SPE Vacuum Manifold with disposable flow control valve liners, a solid-phase extraction (SPE) system, from Supelco Inc. (Bellefonte, PA, USA).

All glassware were treated with sulphochromic mixture at first and, then, washed with different solvents in the order of water, acetone and $n$-hexane prior to use.

\subsection{Analytical procedures}

Water samples collected from Guanting reservoir were pre-filtered using $0.45 \mu \mathrm{m}$ PTFE fiberglass filters 
Table 1

Average recoveries and relative standard deviations (RSDs, \%) for 31 endocrine disrupting pesticides in water and sediment fortified at $0.05,0.1,0.5\left(\mu \mathrm{g} 1^{-1}\right)$ in water and $0.5,5.0,50(\mu \mathrm{g} / \mathrm{kg})$ in sediment

\begin{tabular}{|c|c|c|c|c|}
\hline \multirow[t]{2}{*}{ Pesticides } & \multicolumn{2}{|l|}{ Water } & \multicolumn{2}{|l|}{ Sediment } \\
\hline & Mean recoveries $(\%)$ & RSD ( $\%)$ & Mean recoveries $(\%)$ & RSD $(\%)$ \\
\hline $\mathrm{IS}^{\mathrm{a}}$ & 97 & \pm 2 & 92 & \pm 5 \\
\hline Trifluralin & 90 & \pm 6 & 84 & \pm 4 \\
\hline$\alpha-\mathrm{HCH}$ & 87 & \pm 4 & 84 & \pm 6 \\
\hline $\mathrm{HCB}^{\mathrm{b}}$ & 90 & \pm 3 & 95 & \pm 5 \\
\hline$\beta-\mathrm{HCH}$ & 78 & \pm 4 & 73 & \pm 7 \\
\hline$\gamma-\mathrm{HCH}$ & 99 & \pm 6 & 93 & \pm 5 \\
\hline Dicofol & 72 & \pm 5 & 73 & \pm 6 \\
\hline$\delta-\mathrm{HCH}$ & 77 & \pm 7 & 81 & \pm 5 \\
\hline Acetochlor & 82 & \pm 5 & 88 & \pm 5 \\
\hline Heptachlor & 96 & \pm 7 & 93 & \pm 5 \\
\hline Alachlor & 75 & \pm 7 & 74 & \pm 8 \\
\hline Aldrin & 101 & \pm 3 & 93 & \pm 7 \\
\hline Metolachlor & 71 & \pm 4 & 73 & \pm 6 \\
\hline Chlorpyriphos & 83 & \pm 4 & 86 & \pm 5 \\
\hline $\mathrm{HEPO}^{\mathrm{c}}$ & 99 & \pm 5 & 95 & \pm 7 \\
\hline$\gamma$-chlordane & 90 & \pm 6 & 90 & \pm 8 \\
\hline Endosulfan I & 92 & \pm 5 & 90 & \pm 4 \\
\hline$\alpha$-chlordane & 93 & \pm 6 & 87 & \pm 7 \\
\hline Dieldrin & 90 & \pm 5 & 85 & \pm 4 \\
\hline$p, p^{\prime}-\mathrm{DDE}$ & 96 & \pm 3 & 98 & \pm 5 \\
\hline Endrin & 97 & \pm 7 & 103 & \pm 5 \\
\hline Nitrofen & 83 & \pm 4 & 85 & \pm 6 \\
\hline Endosulfan II & 103 & \pm 6 & 97 & \pm 6 \\
\hline$p, p^{\prime}-\mathrm{DDD}$ & 89 & \pm 5 & 84 & \pm 4 \\
\hline$o, p^{\prime}$-DDT & 73 & \pm 7 & 73 & \pm 7 \\
\hline Endrin aldehyde & 89 & \pm 4 & 98 & \pm 6 \\
\hline Endosulfan sulfate & 72 & \pm 6 & 75 & \pm 8 \\
\hline$p, p^{\prime}$-DDT & 73 & \pm 7 & 71 & \pm 7 \\
\hline Methoxychlor & 84 & \pm 5 & 85 & \pm 8 \\
\hline Cypermethrin & 76 & \pm 4 & 76 & \pm 8 \\
\hline Fenvalerate & 89 & \pm 5 & 83 & \pm 5 \\
\hline Deltamethrin & 70 & \pm 7 & 71 & \pm 7 \\
\hline
\end{tabular}

${ }^{\text {a }}$ IS = Internal Standard.

b $\mathrm{HCB}=$ hexachlorobenzene.

c $\mathrm{HEPO}=$ heptachlor epoxide.

(Millipore, Bedford, MA, USA) to eliminate particulate matter. Up to 11 of water samples were extracted by SPE following the revised method after Nogueira et al. (2004). An IS was added to each water sample $(0.05 \mu \mathrm{g}$ IS per 1.01 water). Each of Oasis ${ }^{\circledR}$ HLB cartridges was conditioned with $5 \mathrm{ml}$ of methanol/ACN $(50 / 50, \mathrm{v} / \mathrm{v})$, $5 \mathrm{ml}$ of methanol and $5 \mathrm{ml}$ of ultra-pure water and slowly aspirated $(-0.2$ bar). Water samples were passed through the cartridges at a flow rate of $4 \mathrm{ml} \mathrm{min}^{-1}$ under vacuum $(-0.3$ bar). The column was wash with $2 \times 4 \mathrm{ml}$ of ultra-pure water, followed by vacuum dry for $2 \mathrm{~min}$. Subsequently, the elution took place with $3 \times 4 \mathrm{ml}$ of methanol/ACN (50/50, v/v). After water being removed from the extracts by anhydrous $\mathrm{Na}_{2} \mathrm{SO}_{4}$, the extract was reduced in volume to dryness under a gentle stream of nitrogen in a water bath. The dry residues obtained were re-dissolved in $0.5 \mathrm{ml}$ of acetone for $\mathrm{GC}$ determination. For blank assays the same procedure as above was performed using water samples with an IS spiked.

After returning the laboratory, routine wet sediment sample analyses were done as follows: the water content was determined by drying about $20 \mathrm{~g}$ of wet sediments for $12 \mathrm{~h}$ (or to constant weight) at $105^{\circ} \mathrm{C}$. The dried sediment was heated at $550{ }^{\circ} \mathrm{C}$ for $1 \mathrm{~h}$ in order to determine the organic matter (Golterman et al., 1983; Hakanson and Jansson, 1983). Silt and clay analyses of sediment samples were done by pipette analyses (Carver, 1971). $\mathrm{pH}$ values were determined by a $\mathrm{pH}$ meter (pHs-2, Shanghai 2nd Analytical Instrument Factory, China). Each sediment sample was centrifuged $(4000 \mathrm{rpm}, \mathrm{Q} /$ 1BL001-94, Beijing Centrifuge Instrument Factory, China) at $4{ }^{\circ} \mathrm{C}$ to obtain pore water in sediment. After 
being pre-filtered using $0.45 \mu \mathrm{m}$ PTFE fiberglass filters, the pore water $(300 \mathrm{ml})$ was extracted and analyzed using the same procedure as described as water samples. Twenty grams (wet weight) of the centrifuged sediments (the wet-to-dry weight ratios of the sediments have been determined and spiked with IS to quantify the overall recovery of the procedures) was weighted into a glass vial and sonicated for $30 \mathrm{~min}$ with $2 \times 40 \mathrm{ml}$ of methanol/ACN $(50 / 50, v / v)$ in an ultrasonic bath (Institute of acoustics, CAS, China). Because the centrifuged sediment still contains significant volume of water, the extraction efficiency of pesticides may be low. In the case, sediment samples were extracted twice by being sonicated with methanol/ACN and centrifuged. Extracts were transferred into glass flasks by careful decantation. The extracts were evaporated to about $25 \mathrm{ml}$ under vacuum with a rotavapor (Büchi, Flawil, Switzerland) with a water bath (about $80^{\circ} \mathrm{C}$ ). The concentrated extracts were re-extracted with hexane-ether $(6: 94,15: 85,50: 50$, v:v) three times, with $10 \mathrm{ml}$ quantities each time. The organic phase was evaporated to near dryness. The residues were cleaned up by a Florosil column $(8 \mathrm{~mm}$ i.d. $\times 350 \mathrm{~mm}$ ) containing $8 \mathrm{~g}$ of Florosil. Anhydrous sodium sulfate $(2 \mathrm{~cm})$ was added to the top of the column in order to remove water. The column was then eluted first with $4 \mathrm{ml}$ of $\mathrm{DCM} / n$-hexane $(20 / 80, \mathrm{v} / \mathrm{v})$ and the solution discarded. Further $25 \mathrm{ml}$ of $\mathrm{DCM} / n$-hexane $(20 / 80, v / v)$ was needed to elute to obtain pesticides. After collection, the eluate was evaporated near dryness under a nitrogen flow. Subsequently, the sample was dissolved in $1 \mathrm{ml}$ of acetone for GC determination. Sulfur was noted in many of the sediment samples, and copper powder was added to eliminate the sulfur interference in the chromatograms. However, no significant improvement was found in the later part of the chromatogram where the tested pesticide peaks dominated in current experiment. Therefore, copper was not used as a cleanup step.

Determination was done by a GC system with a micro cell electron capture detector ( $\mu$-ECD) and split/ splitless injector (Agilent Series 6890), equipped with ChemStation Software. A fused silica capillary column (HP-5, $30 \mathrm{~m} \times 0.25 \mathrm{~mm}$ i.d. and $0.25 \mu \mathrm{m}$ film thickness) was used. The oven temperature was programmed from 80 (equilibrium time $1 \mathrm{~min}$ ) to $150^{\circ} \mathrm{C}$ at a rate of $10 \mathrm{~min}^{-1}$ and held for $2 \mathrm{~min}$, from 150 to $180^{\circ} \mathrm{C}$ at a rate of $2 \mathrm{~min}^{-1}$ and held for $1 \mathrm{~min}$ then rising to $250{ }^{\circ} \mathrm{C}$ at a rate of $5 \mathrm{~min}^{-1}$ and held for $1 \mathrm{~min}$. The temperature was finally increased to $290{ }^{\circ} \mathrm{C}$ at a rate of $8 \mathrm{~min}^{-1}$ and held for $5 \mathrm{~min}$; with a total run of $50 \mathrm{~min}$. Nitrogen $(99.999 \%)$ was used as carrier gas and makeup gas. A split/splitless was used in the splitless mode. Injector temperature and the electron capture detector temperature were set at 230 and $310^{\circ} \mathrm{C}$, respectively. The injection volume was of $1 \mu \mathrm{l}$.

\subsection{Identification and quantification}

Before analysis, relevant standards were run to check column performance, peak height, and resolution, and the limits of detection (LOD). With each set of samples analyzed, a solvent blank, a standard mixture and a procedural blank were run in sequence to check for contamination, peak identification and quantification. None of the target compounds were detected in the procedural blanks for water and sediment. Spiked water and sediment samples $\left(0.1 \mu \mathrm{g} \mathrm{l}^{-1}\right.$ of each target compound) were determined with good precision and high recoveries. Chromatograms are shown in Fig. 2(A) for a standard solution of pesticides with an IS spiked. The chromatogram of the spiked blank sample was free of interfering peaks and it showed a satisfactory overlay in terms of retention times with that of the standard solution. The recovery, LOD, and relative standard deviation (RSD) for water were as follows: LOD of target compounds (include IS) ranged from $5.0 \times 10^{-4}$ to $1.5 \times 10^{-2}{\mathrm{ng} 1^{-1}}^{-1}$ for water, and $3.0 \times 10^{-5}$ to $1.5 \times 10^{-3} \mathrm{ng} \mathrm{g}^{-1}$ for sediment. The recovery study performed on blank samples spiked with known levels of the pesticides is summarized in Table 1. Three replicates for each sample have been carried out at three fortification levels $(0.05,0.1$, $0.5 \mu \mathrm{g}^{-1}$ for water and $0.5,5.0,50.0 \mu \mathrm{g} \mathrm{kg}^{-1}$ for sediments, respectively), and the relevant recovery results, given as mean values, were $70-103 \%$ and $71-103 \%$ for water and sediment, respectively. RSD was $2.0-7.0 \%$ and $4.0-8.0 \%$ for water and sediment, respectively. The recoveries are satisfactory for all compounds apart for $o, p^{\prime}$-DDT, endosulfan sulfate, $p, p^{\prime}$-DDT and $\beta$-HCH (lower than $80 \%$ ) and they were corrected for quantification. 2,4,5,6-tetrachloro- $m$-xylene was used as an IS to assess the losses involved in the sample extraction and analysis.

All data were subject to strict quality control procedures including the repeatability of GC/ECD determinations through the analysis of procedural blanks and spiked samples $\left(100 \mathrm{ng} \mathrm{g}^{-1}\right)$ level. Identification was accomplished using relative retention time techniques while quantification was done by comparison of peak areas of samples to those of standards at known concentrations. Identification of those pesticides was confirmed on a number of samples with gas chromatography-mass spectrometry (Agilent 6890 with mass spectrometer Agilent 5973 MSD (Agilent Technologies, USA)). A capillary column $(\mathrm{hp}-35 \mathrm{~ms}, 30 \mathrm{~m} \times 0.25 \mathrm{~mm}$ i.d. and $0.25 \mu \mathrm{m}$ film thickness) was used. The oven temperature was programmed from 70 (initial time $2 \mathrm{~min}$ ) to $150^{\circ} \mathrm{C}$ at $25 \mathrm{~min}^{-1}, 150-200^{\circ} \mathrm{C}$ at a rate of $3 \mathrm{~min}^{-1}$, then 200 $280{ }^{\circ} \mathrm{C}$ at a rate of $8 \mathrm{~min}^{-1}$ and held at $280^{\circ} \mathrm{C}$ for $10 \mathrm{~min}$. Injector temperature was set at $250^{\circ} \mathrm{C}$. The constant pressure was of $20 \mathrm{psi}$ and injection volume was of $2 \mu \mathrm{l}$. 


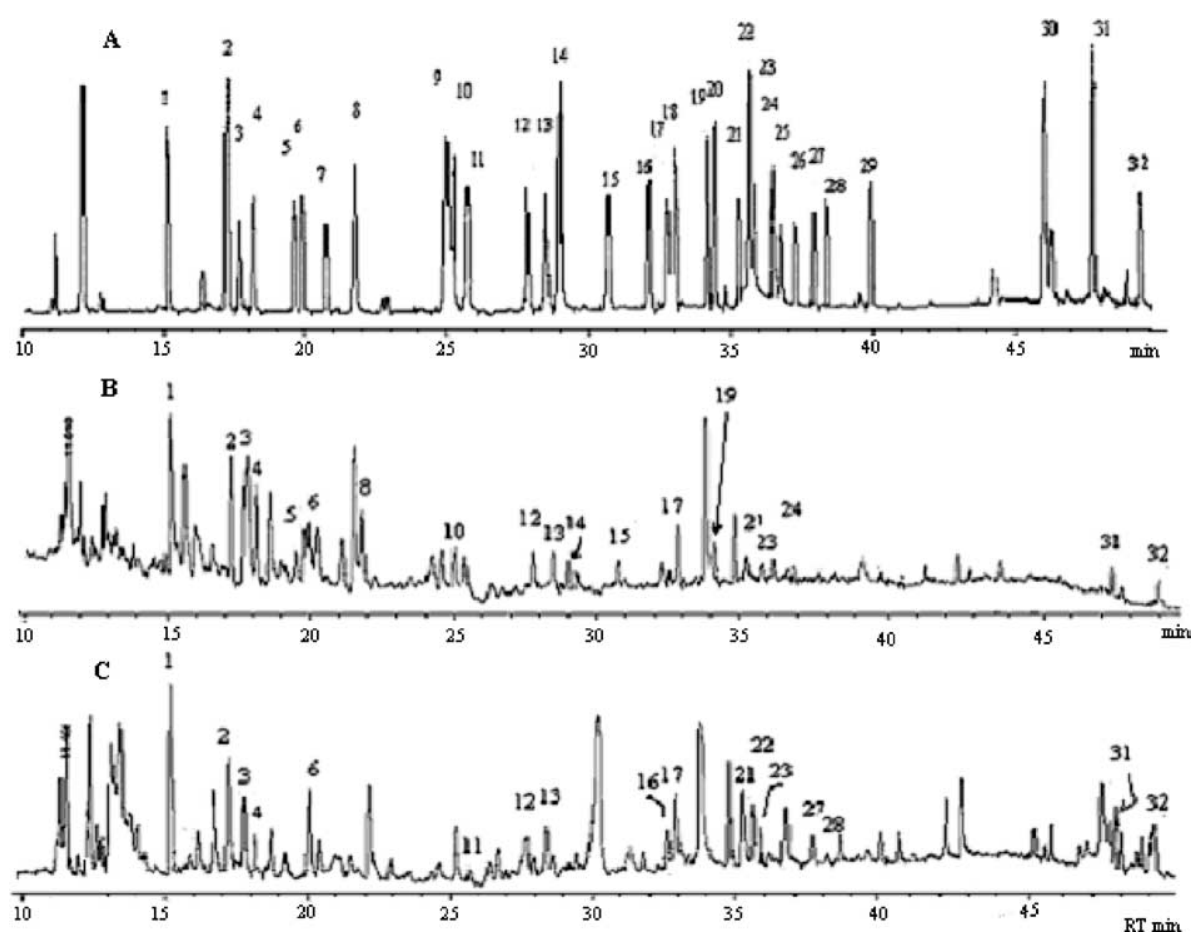

Fig. 2. Chromatograms of a standard mixture of pesticides (at $0.1-0.5 \mu \mathrm{g} \mathrm{g}^{-1}$ concentrations) with an IS spiked (A), and typical chromatogram of endocrine disrupting pesticides studied in water (B) and in sediment sample (C); Peaks: 1, IS (internal standard, 2,4,5,6-tetrachloro- $m$-xylene); 2, trifluralin; 3, $\alpha$-HCH; 4, HCB; 5, $\beta$-HCH; $6, \gamma$-HCH; 7, Dicofol; 8, $\delta$-HCH; 9, acetochlor; 10, heptachlor; 11, alachlor; 12, aldrin; 13, metolachlor; 14, chlorpyriphos; 15, hepachlor epoxide; 16, $\gamma$-chlordan; 17, endosulfan I; 18, $\alpha$ chlordane; 19, dieldrin; 20, $p, p^{\prime}$-DDE; 21, endrin; 22, nitrofen; 23, endosulfan II; 24, $p, p^{\prime}$-DDD; 25, $o, p^{\prime}$-DDT; 26, endrin aldehyde; 27, endosulfan sulphate; 28, $p, p^{\prime}$-DDT; 29, methoxychlor; 30, cypermethrin; 31, fenvalerate; 32, deltamethrin.

\section{Results and discussion}

\subsection{Physicochemical characteristics of sediment and water samples}

Table 2 provides the basic physicochemical parameters of sediment samples collected from the Guanting reservoir. The depth of the water column above the sediment layer was between 8.5 and $1.2 \mathrm{~m}$. The water content of sediments ranged from $36.1 \%$ to $71.5 \%$. The organic matter (denoted by loss on ignition, $\mathrm{LOI} \%$ ) of sediments ranged from $3.98 \%$ to $8.49 \%$. The maximum organic matter of the sediment samples was observed at the sampling site 7 that is located in front of a dam. Sediments with high organic carbon are more likely to adsorb lipophilic organochlorines than are those with lower organic carbon levels. $\mathrm{pH}$ Values of sediments ranged from 7.91 to 8.52 with an average of 8.06 . The physicochemical properties of water samples were also analyzed. The range of $\mathrm{COD}_{\mathrm{Cr}}$ in water samples was between 3.5 and $18.5 \mathrm{mg} \mathrm{l}^{-1}$. The maximum value of $\mathrm{COD}_{\mathrm{Cr}}$ was at site 7 and the minimum was at site 3 . Silt

Table 2

The basic physicochemical properties of surface sediment samples collected from Guanting reservoir

\begin{tabular}{|c|c|c|c|c|c|c|c|}
\hline $\begin{array}{l}\text { Sampling sites/ } \\
\text { geographic positions }\end{array}$ & $\begin{array}{l}\text { Site } \\
\text { description }\end{array}$ & $\begin{array}{l}\text { Water } \\
\text { depth }(\mathrm{m})\end{array}$ & $\begin{array}{l}\text { Water } \\
\text { content }(\mathrm{g} / \mathrm{kg})\end{array}$ & $\begin{array}{l}\text { Loss on ignition, } \\
\text { LOI }(\%)\end{array}$ & $\mathrm{pH}$ & $\begin{array}{l}\text { Clay } \\
(\%)\end{array}$ & $\begin{array}{l}\text { Silt } \\
(\%)\end{array}$ \\
\hline $1\left(40^{\circ} 27^{\prime} 16^{\prime \prime} \mathrm{N}, 115^{\circ} 59^{\prime} 34^{\prime \prime} \mathrm{E}\right)$ & Yanqing & 1.2 & 40.0 & 7.13 & 7.97 & 24.8 & 52.1 \\
\hline $2\left(40^{\circ} 16^{\prime} 08^{\prime \prime} \mathrm{N}, 115^{\circ} 35^{\prime} 21^{\prime \prime} \mathrm{E}\right)$ & Liushawang & 1.5 & 42.8 & 4.58 & 8.12 & 18.5 & 37.7 \\
\hline $3\left(40^{\circ} 16^{\prime} 51^{\prime \prime} \mathrm{N}, 115^{\circ} 35^{\prime} 08^{\prime} \mathrm{E}\right)$ & Erdaojian & 1.5 & 69.7 & 3.98 & 8.52 & 8.9 & 28.2 \\
\hline $4\left(40^{\circ} 18^{\prime} 03^{\prime \prime} \mathrm{N}, 115^{\circ} 36^{\prime} 58^{\prime \prime} \mathrm{E}\right)$ & Baizhaihe & 1.5 & 59.2 & 5.59 & 8.03 & 19.8 & 37.4 \\
\hline $5\left(40^{\circ} 16^{\prime} 11^{\prime \prime} \mathrm{N}, 115^{\circ} 20^{\prime} 10^{\prime \prime} \mathrm{E}\right)$ & Baohaoqiao & 5.5 & 36.1 & 6.72 & 7.95 & 20.3 & 44.6 \\
\hline $6\left(40^{\circ} 16^{\prime} 11^{\prime \prime} \mathrm{N}, 115^{\circ} 35^{\prime} 10^{\prime \prime} \mathrm{E}\right)$ & Yanghekou & 5.8 & 64.8 & 6.81 & 7.92 & 21.4 & 39.8 \\
\hline $7\left(40^{\circ} 15^{\prime} 07^{\prime \prime} \mathrm{N}, 115^{\circ} 36^{\prime} 09^{\prime \prime} \mathrm{E}\right)$ & Baqian & 8.5 & 71.5 & 8.49 & 7.91 & 30.4 & 57.5 \\
\hline
\end{tabular}


and clay analyses of sediment samples were done by pipette analyses method according to Carver (1971). Clay and silt content (\%) denote the texture of sediment samples. The maximum value of sum of clay (\%) and silt (\%) was the sample from site $7(87.9 \%)$.

\subsection{Levels of pesticides residues in sediment and water samples}

The analyzed samples showed the presence of pesticides in water and sediment at concentrations above the method of detection limits. Pesticides detected in water and sediment were listed in Table 3 including $p, p^{\prime}$-DDE, $p, p^{\prime}$-DDD, $p, p^{\prime}$-DDT, $o, p^{\prime}$-DDT, $\alpha-, \beta-$, $\gamma$ - and $\delta$ - $\mathrm{HCH}, \mathrm{HCB}$, heptachlor, HEPO, $\alpha$-chlordane, $\gamma$-chlordane, aldrin, endosulfan I \& II, endosulphane sulphate, endrin aldehyde, endrin, methoxychlor, dicofol, acetochlor, alachlor, metolachlor, chlorpyriphos, nitrofen, trifluralin, cypermethrin, fenverate and deltamethrin. Typical chromatograms of pesticides studied in water and sediment samples were showed in Fig. 2(B) and (C), respectively.

The results of endocrine disrupting pesticide residues in sediment, pore water and water samples are shown in Table 3. Concentrations of pesticides ranged from 7590 to $36000 \mathrm{pg} \mathrm{g}^{-1}$ (dry weight) for sediment samples, from

Table 3

Range, Mean and Standard Deviations (SD) of pesticides concentrations in water $\left(\mathrm{ng} \mathrm{l}^{-1}\right)$, pore water $\left(\mathrm{ng} \mathrm{l}^{-1}\right)$ and sediment $\left(\mathrm{pg} \mathrm{g}^{-1}\right.$, dry wt.) samples

\begin{tabular}{|c|c|c|c|c|c|c|c|c|c|}
\hline \multirow[t]{2}{*}{ Compounds } & \multicolumn{3}{|c|}{ Water $\left(\mathrm{ng} \mathrm{l}^{-1}\right)^{\mathrm{a}}$} & \multicolumn{3}{|c|}{ 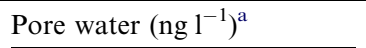 } & \multicolumn{3}{|c|}{ Sediment $\left(\mathrm{pg} \mathrm{g}^{-1}\right)^{\mathrm{a}}$} \\
\hline & Range & Mean & $\mathrm{SD}$ & Range & Mean & SD & Range & Mean & SD \\
\hline Trifluralin & $3.41-5.15$ & 4.5 & 1.32 & $N^{b}-83.6$ & 44.0 & 27.2 & $120-1010$ & 127 & 311 \\
\hline$\alpha-\mathrm{HCH}$ & $1.32-17.8$ & 7.62 & 3.57 & $2.20-66.4$ & 24.8 & 22.6 & $56.2-159$ & 149 & 30.4 \\
\hline $\mathrm{HCB}^{\mathrm{c}}$ & $1.43-27.3$ & 12.4 & 8.82 & $12.2-58.5$ & 18.9 & 13.0 & $55.2-494$ & 146 & 115 \\
\hline$\beta-\mathrm{HCH}$ & $12.3-60.5$ & 31.1 & 15.6 & $12.6-79.8$ & 45.6 & 20.6 & $1530-6000$ & 1730 & 1430 \\
\hline$\gamma-\mathrm{HCH}$ & ND-120 & 31.3 & 22.7 & ND-13.7 & 1.32 & 11.5 & $1.32-140$ & 104 & 35.8 \\
\hline Dicofol & ND-2.60 & 0.91 & 0.82 & ND-28.5 & 4.00 & 8.42 & ND-62.7 & 48.7 & 15.4 \\
\hline$\delta-\mathrm{HCH}$ & $0.39-4.62$ & 1.24 & 0.73 & ND-159 & 44.5 & 62.8 & $952-4670$ & 1050 & 1770 \\
\hline Acetochlor & ND-1.50 & 0.55 & 0.41 & ND-26.5 & 9.58 & 4.18 & $50.0-188$ & 67.4 & 168 \\
\hline Heptachlor & $0.66-8.50$ & 0.98 & 3.14 & ND-50.8 & 7.2 & 25.4 & $7.20-101$ & 16.3 & 30.8 \\
\hline Alachlor & ND-5.68 & 1.72 & 2.08 & ND-41.2 & 9.1 & 13.0 & ND-219 & 87.2 & 61.4 \\
\hline Aldrin & $1.65-32.4$ & 23.0 & 8.05 & $132-798$ & 146 & 130 & $132-1300$ & 472 & 429 \\
\hline Metolachlor & $15.5-27.2$ & 22.7 & 5.21 & $42.5-138$ & 45.3 & 29.5 & $65.8-297$ & 74.2 & 145 \\
\hline Chlorpyriphos & $0.30-1.89$ & 1.5 & 0.44 & $1.90-8.77$ & 3.3 & 2.81 & $52.9-165$ & 65.9 & 60.0 \\
\hline $\mathrm{HEPO}^{\mathrm{d}}$ & $0.49-12.0$ & 4.10 & 2.86 & ND-12.9 & 5.12 & 3.45 & $10.8-232$ & 78.2 & 102.5 \\
\hline$\gamma$-chlordane & $0.53-30.8$ & 7.26 & 12.9 & ND-10.2 & 1.86 & 2.04 & $46.6-398$ & 76.4 & 78.1 \\
\hline Endosulfan I & $0.07-13.8$ & 1.48 & 11.9 & $5.05-38.3$ & 16.6 & 7.03 & $15.1-58.0$ & 38.5 & 12.7 \\
\hline$\alpha$-chlordane & $0.31-8.2$ & 2.86 & 1.99 & ND-34.9 & 17.8 & 7.82 & ND-144 & 45.5 & 32.5 \\
\hline Dieldrin & ND-4.54 & 0.59 & 2.91 & ND-12.9 & 8.52 & 4.04 & $17.2-219$ & 48.7 & 40.8 \\
\hline$p, p^{\prime}-\mathrm{DDE}$ & $1.64-153$ & 46.0 & 24.4 & $6.20-51.3$ & 43.2 & 20.4 & $726-6400$ & 854 & 1470 \\
\hline Endrin & ND-14.1 & 8.03 & 4.34 & ND-6.11 & 4.58 & 1.47 & $43.8-513$ & 61.4 & 148 \\
\hline Nitrofen & ND-2.28 & 1.30 & 0.35 & ND-8.28 & 3.33 & 2.75 & $9.38-42.5$ & 18.5 & 9.45 \\
\hline Endosulfan II & ND-12.2 & 0.67 & 2.24 & ND-5.24 & 4.21 & 1.08 & $8.25-350$ & 184 & 310 \\
\hline$p, p^{\prime}-\mathrm{ODD}$ & ND-2.14 & 0.56 & 1.60 & ND-6.89 & 3.19 & 1.95 & ND-74.2 & 42.5 & 12.8 \\
\hline$o, p^{\prime}$-DDT & $4.14-161$ & 35.2 & 29.0 & ND-47.5 & 40.5 & 10.4 & $2920-9610$ & 3310 & 1340 \\
\hline Endrin aldehyde & ND-5.00 & 1.45 & 0.71 & $6.6-24.5$ & 18.6 & 6.61 & $36.6-147$ & 68.4 & 38.4 \\
\hline Endosulfan & $4.65-51.4$ & 22.6 & 12.4 & $58.4-195$ & 138.4 & 50.8 & $48.4-1050$ & 458 & 108 \\
\hline$p, p^{\prime}$-DDT & ND-30.0 & 11.4 & 5.16 & ND-577 & 42.8 & 166 & $525-1180$ & 1090 & 201 \\
\hline Methoxychlor & ND-21.6 & 4.07 & 3.65 & ND-67.3 & 29.3 & 18.8 & $35.4-352$ & 48.2 & 62.6 \\
\hline Cypermethrin & ND-1.89 & 1.25 & 0.20 & ND-8.87 & 3.18 & 2.94 & ND-8.77 & 3.48 & 1.94 \\
\hline Fenvalerate & ND-3.22 & 2.30 & 0.58 & ND-26.3 & 6.32 & 5.54 & $45.4-158$ & 70.3 & 31.9 \\
\hline Deltamethrin & ND-6.28 & 4.30 & 1.32 & ND-54.2 & 31.8 & 14.5 & $78.6-301$ & 81.4 & 108 \\
\hline$\sum \mathrm{OCPs}^{\mathrm{e}}$ & $29.6-795$ & 253 & 179 & $235-2320$ & 576 & 589 & $7170-33600$ & 10200 & 7640 \\
\hline Total & $48.8-890$ & 295 & 191 & $279-2740$ & 735 & 699 & $7590-3600$ & 10700 & 8700 \\
\hline
\end{tabular}

${ }^{\text {a }}$ Values are mean of triplicate analyses for seven samples from different sampling sites.

b ND means not detected.

c $\mathrm{HCB}=$ hexachlorobenzene.

${ }^{\mathrm{d}} \mathrm{HEPO}=$ heptachlor epoxide.

e OCPs = organochlorine pesticides. 
279 to $2740 \mathrm{ng}^{-1}$ for pore waters and from 48.8 to $890 \mathrm{ng}^{-1}$ for water samples respectively, with a mean concentration of $10700 \mathrm{pg} \mathrm{g}^{-1}$ (dry weight) in sediment, $1360 \mathrm{ng}^{-1}$ in pore water, $295 \mathrm{ng} \mathrm{l}^{-1}$ in water respectively. Because of limited research data on these total 31 pesticides in sediment, in pore water, and in water, it could not be compared with others. When comparing OCPs in water and in sediment, it was found that, the levels of total OCPs both in water (29.6-795 $\mathrm{ng}^{-1}$, with a mean of $253 \mathrm{ng}^{-1}$ ) and in sediment (7170$33600 \mathrm{pg} \mathrm{g}^{-1}$, with a mean of $10200 \mathrm{pg} \mathrm{g}^{-1}$ ) from Guanting reservoir are lower than that from Beijing Tonghui River (Zhang et al., 2004). However the level in water is higher than that of several other locations on the east coast of China such as the Jiulong River Estuary (115.4-414.7 $\mathrm{ng}^{-1}$, with a mean of $191.5 \mathrm{ng}^{-1}$; Zhang

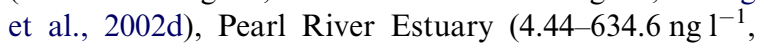
with a mean of $88.31 \mathrm{ng}^{-1}$; Zhang et al., 2002c), and South China Sea $\left(1.27-121.8 \mathrm{ng}^{-1}\right.$, with a mean of $16.49 \mathrm{ng}^{-1}$; Zhang et al., 2002c).

The data show that water in Guanting reservoir is moderately polluted by pesticides. The levels of endocrine disrupting pesticides in sediment samples recorded in this study are compared with those of other countries. $\mathrm{HCH}$ concentrations were found to be in the range of 0.24-10.8 $\mathrm{ng} \mathrm{g}^{-1}$ dry wt. (Table 3). Concentrations of $\gamma$-HCH (commercial name Lindane) in sediment samples $\left(0.0013-0.12 \mathrm{ng} \mathrm{g}^{-1}\right)$ is lower than that reported from the Romania coastline by Fillmann et al. (2002) and from Indian cities by Sarkar and Sen Gupta
(1991) and Iwata et al. (1994a). Our results also showed lower mean concentrations of total DDTs in sediments than concentrations found in Turkey coastline and rivers (7-71 $\mathrm{ng} \mathrm{g}^{-1}$ ) (Bakan et al., 1999; Bakan and Ariman, 2004) and in the Ukranian coastline of the Black Sea in the past (Fillmann et al., 2002) but similar to that in cities in Japan (2.5-12 $\mathrm{ng} \mathrm{g}^{-1}$ ) (Iwata et al., 1994a). Table 4 showed the comparison of the results of OCPs (DDTs, HCHs and CHLs) residues in sediment samples from the studied sites with those in the sediments in rivers, lakes or estuaries from other locations.

The total DDT (sum of $p, p^{\prime}$-DDE, $p, p^{\prime}$-DDD, $p, p^{\prime}$ DDT and $o, p^{\prime}$-DDT) and $\gamma-\mathrm{HCH}$ in sediment samples were $3.25-17.6 \mathrm{ng} \mathrm{g}^{-1}$ and $0.0013-0.12 \mathrm{ng} \mathrm{g}^{-1}$, respectively. And levels of all detected pesticides were below the New York sediment quality criteria and guidelines to protect wildlife from adverse effect associated with bioaccumulation of persistent substance in aquatic biota (total DDT 100 and $\gamma$-HCH $1500 \mathrm{ng} \mathrm{g}^{-1}$ dry wt.) (Mac Doanld, 1994). The concentrations of pesticides in water (Table 3) are generally lower than the Chinese standards for surface water $\left(0.5 \mu \mathrm{g} 1^{-1}\right.$ for OCPs) and tap water $\left(0.5 \mu \mathrm{g} 1^{-1}\right.$ for the sum of pesticides and $0.1 \mu \mathrm{g} 1^{-1}$ for individual pesticide). According to Chinese guideline (SEPA, 1999), in the grade 1-3 surface water, the concentration of $\mathrm{HCHs}$ should be less than $5000 \mathrm{ng}^{-1}$, DDTs should be less than $1000 \mathrm{ng} 1^{-1}$. (According to USEPA guideline, the critical value for DDT is $1000 \mathrm{ng}^{-1}$ too.) However, values in a few sites are considerably high for use as a drinking water. Among the

Table 4

Comparison of organochlorine pesticides (DDTs, HCHs and CHLs) concentrations (ng g ${ }^{-1}$ dry wt.) in the sediments in rivers, lakes or estuaries from other locations

\begin{tabular}{llllll}
\hline Locations & Year & DDTs $^{\mathrm{a}}$ & CHLs $^{\mathrm{b}}$ & HCHs $^{\mathrm{c}}$ & References $^{\text {Washington, DC, USA }}$ \\
\hline Wase Prodelta, France & 1991 & $7-160$ & $5-153$ & NA $^{\mathrm{d}}$ & Wade et al. (1994) \\
Rhone & 1990 & $73-704$ & NA & NA & Tanabe et al. (1994) \\
Ebro Prodelta, Spain & 1990 & $0.8-93$ & NA & NA & Tanabe et al. (1994) \\
Ebro River, Spain & $1995-1996$ & $0.4-52$ & NA & $0.001-0.038$ & Fernandez et al. (1999) \\
Lake Baikal, Russia & 1992 & $0.014-2.7$ & n.d. -0.003 & $0.019-0.12$ & Iwata et al. (1994b) \\
Ulsan Bay, Korea & 1999 & $0.01-41.9$ & $0.01-3.96$ & $0.02-4.55$ & Khim et al. (2001) \\
Masan Bay, Korea & 1998 & $0.07-7.83$ & n.d.-0.18 & $0.01-0.59$ & Khim et al. (1999) \\
Northern Coast, Vietnam & 1998 & $6.2-10.4$ & NA & $1.2-33.7$ & Nhan et al. (1999) \\
Yesilirmak river, Turkey (wet wt.) & $1998-2000$ & 71 & NA & $14-16$ & Bakan and Ariman (2004) \\
Wu-Shi estuary, Taiwan & $1997-1998$ & n.d.-11.4 & $0.46-27.2$ & $0.99-14.5$ & Doong et al. (2002) \\
Hong Kong, China & $1997-1998$ & $0.27-14.8$ & n.d.-11. 3 & $0.1-16.7$ & Richardson and Zheng (1999) \\
Daya Bay, China & 2000 & $0.14-20.3$ & NA & $0.32-4.16$ & Zhou et al. (2001) \\
Yangtze river estuaries, China & 2001 & n.d.-0.57 & NA & n.d.-30.4 & Liu et al. (2003) \\
Minjiang river estuaries, China & 1999 & $1.57-13.6$ & NA & $2.99-16.2$ & Zhang et al. (2003). \\
Beijing Guanting reservoir, China & $2003-2004$ & $2.85-16.6$ & $0.087-0.64$ & 0.2410 .8 & This study \\
\hline
\end{tabular}

\footnotetext{
${ }^{\mathrm{a}} \mathrm{DDTs},=\sum\left(o, p^{\prime}-\mathrm{DDT}+p, p^{\prime}-\mathrm{DDT}+p, p^{\prime}-\mathrm{DDE}+p, p^{\prime}-\mathrm{DDD}\right)$.

${ }^{\mathrm{b}} \mathrm{HCHs}=\sum(\alpha-\mathrm{HCH}+\beta-\mathrm{HCH}+\gamma-\mathrm{HCH}+\delta-\mathrm{HCH})$.

${ }^{\mathrm{c}}$ CHLs $=\sum(\gamma$-chlordane $+\alpha$-chlordane $)$.

${ }^{\mathrm{d}} \mathrm{NA}=$ no data available.

e n.d. = not detected.
} 
analyzed pesticides, $p, p^{\prime}$-DDE, $o, p^{\prime}$-DDT, $\beta$-HCH, $\gamma$ $\mathrm{HCH}$, endosulfan sulfate and aldrin were the most abundant pesticides in water while $p, p^{\prime}$-DDT, $\delta$ - $\mathrm{HCH}$, $\beta$-HCH, $p, p^{\prime}$-DDE, $p, p^{\prime}$-DDT and endosulfan sulfate were the most abundant in sediment, and $p, p^{\prime}$-DDT, aldrin, endosulfan sulfate, $\delta-\mathrm{HCH}, \beta-\mathrm{HCH}$ and $p, p^{\prime}$-DDE were the most abundant in pore water. In comparison with results from the Beijing Tonghui River (Zhang et al., 2004) alpha- $\mathrm{HCH}, \delta-\mathrm{HCH}$, heptachlor, endosulfan II and DDT were the major pesticides in water while heptachlor, dieldrin and DDE composed of $95 \%$ of total pesticides in sediment in Tonghui River. It was reported that $o, p^{\prime}$-DDT is contained in technical dicofol as impurity and that a possible cause of $o, p^{\prime}$-DDT at relatively high concentrations in environment may be present application of dicofol in China (Qiu et al., 2004). Relatively high concentrations of $o, p^{\prime}$-DDT was found in water, pore water and sediment samples in this study (Table 3), which suggested the possibility of present use of dicofol, a nonsystemic acaricide used extensively for the control of mites, in China even though more studies are needed to confirm.

Other pesticides considered in this work (metolachlor, trifluralin, nitrofen acetochlor, alachlor, chlorpyriphos, cypermethrin, deltamethrin and fenverlate) are compounds frequently used in this region and are associated with health risks as endocrine disrupting pesticides. However, the data for their residues in water or in sediments were scarce, which can be attributed to their lesser persistence. But these currently used pesticides were monitored in Central American river ecosystems (Castillo et al., 2000; Castilho et al., 2000; Volker Laabs et al., 2002.) demonstrated that these substances are also relevant contaminants in the aquatic environment.

Metolachlor, deltamethrin, trifluralin, nitrofen and acetochlor were the pesticides most frequently found in water and sediments from Guanting reservoir. This reflects the abundant current use of them in the area and the river watersheds. These results also suggest that the use of the pesticides in the agricultural system should be minimized. The levels of metolachlor, trifluralin, nitrofen acetochlor, alachlor and chlorpyriphos in surface water and sediment samples recorded in this study are compared with those of the Northeastern Pantanal Basin, Brazil. Total concentrations of metolachlor, trifluralin, nitrofen acetochlor, alachlor and chlorpyriphos in water samples (in the range of $19.2-52.7 \mathrm{ng} \mathrm{l}^{-1}$, with a mean value $36.5 \mathrm{ng}^{-1}$ ), in sediment samples (in the range of $707-3410 \mathrm{pg} \mathrm{g}^{-1}$, with a mean value $1510 \mathrm{pg} \mathrm{g}^{-1}$ ) is lower than that reported from the Northeastern Pantanal Basin, Brazil, by Volker Laabs et al. (2002), where total concentrations were found in the range of $31-56 \mathrm{ng}^{-1}$, with a mean value $55 \mathrm{ng}^{-1}$.

Cypermethrin, deltamethrin and fenvalerate are in the class of synthetic pyrethroids that have been intro- duced over the past two decades for a variety of insecticidal uses. Each of these chemicals is highly lipophilic and in aquatic environments trend to strongly adsorb to sediments (USEPA, 1999). They were frequently found in water and sediments from Guanting reservoir. This reflects the abundant current use of them in the area and the river watersheds. Among cypermethrin, deltamethrin and fenvalerate, deltamethrin had the highest concentration but cypermethrin was most frequently found in the water and sediment samples from Guanting reservoir.

Once entering water bodies, pesticides will partition between water, pore water and sediments. Although sediments may act a reservoir for these contaminations, they can also release the contaminations back into the overlying water under certain conditions. The investigation of pesticides in sediments and water column is therefore an important approach to assess the fate of these contaminations. The results showed that the concentrations of pesticides in sediment were higher than those in surface water and pore water in Guanting reservoir. It may be due to the fact that organic hydrophobic pollutants tend to stay in the sediments (Zhang et al., 2004). In order to estimate environmental distribution and fate of the pesticides, the flux composition of pesticides in surface water, pore water and sediments were calculated as

$$
\begin{gathered}
P_{\mathrm{w}}^{\%}=C_{\mathrm{w}} / \sum P \times 100 \% \\
P_{\mathrm{p}}^{\%}=C_{\mathrm{p}} / \sum P \times 100 \% \\
P_{\mathrm{s}}^{\%}=C_{\mathrm{s}} / \sum P \times 100 \% \\
\sum P=C_{\mathrm{w}}+C_{\mathrm{p}}+C_{\mathrm{s}}
\end{gathered}
$$

where $P_{\mathrm{w}}, P_{\mathrm{p}}$ and $P_{\mathrm{s}}$ denote the flux composition of individual pesticide in surface water, in pore water and in sediments, respectively; $C_{\mathrm{w}}, C_{\mathrm{p}}$ and $C_{\mathrm{s}}$ denote flux of individual pesticide in surface water, in pore water and in sediments, respectively. $P$ denote the total flux of individual pesticide in surface water, in pore water and in sediments.

For all 31 pesticides, the flux composition of pesticides in sediment, pore water and in surface water were showed in Fig. 3. From Fig. 3, the flux compositions (\%) of individual pesticides were generally in the same order of magnitude as in sediment, pore water and in surface water with an exception of $\gamma-\mathrm{HCH}$. The results indicate a distribution model of pesticides in the reservoir though more studies need be done to understand why there are high ratios about $\gamma-\mathrm{HCH}$.

From Fig. 3, high flux composition (more than 10\%) of individual pesticides in water for $\gamma-\mathrm{HCH}$, metolachlor and cypermethrin and relatively high flux composition (more than 20\%) of individual pesticides in pore water 


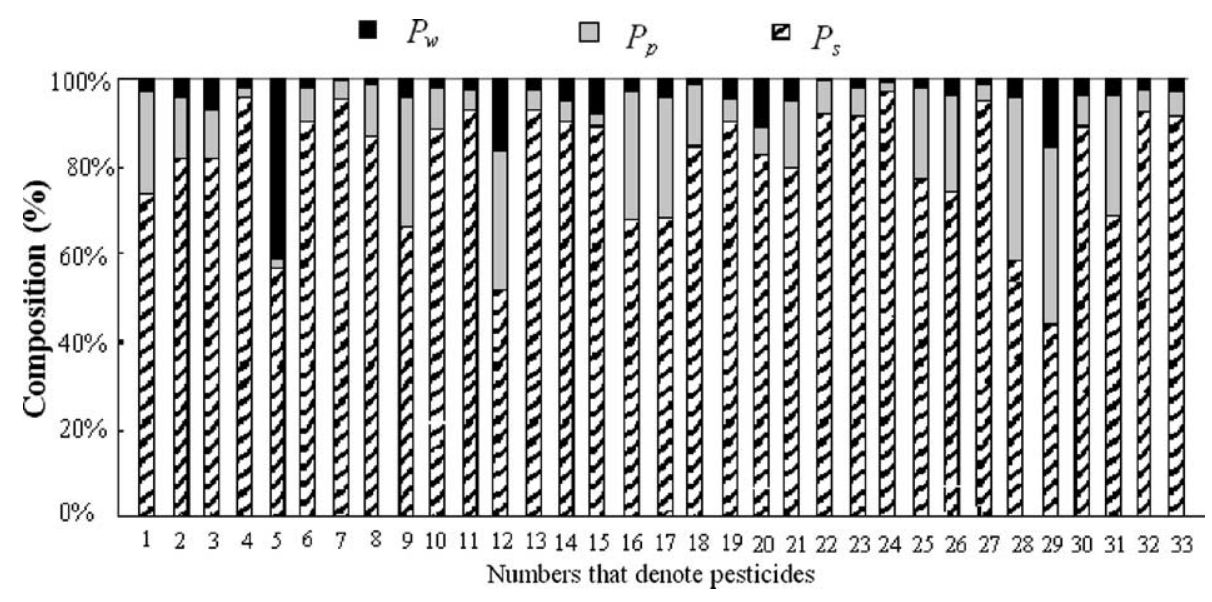

Fig. 3. The composition of pesticides in surface water, pore water and sediments; $P_{\mathrm{w}}, P_{\mathrm{p}}$ and $P_{\mathrm{s}}$ denote the flux composition of individual pesticide in surface water, in pore water and in sediments, respectively (1, trifluralin; $2, \alpha-\mathrm{HCH} ; 3, \mathrm{HCB} ; 4, \beta-\mathrm{HCH} ; 5, \gamma-$ $\mathrm{HCH}$; 6, dicofol; 7, $\delta$-HCH; 8, acetochlor; 9, heptachlor; 10, alachlor; 11, aldrin; 12, metolachlor; 13, chlorpyriphos; 14, hepachlor epoxide; 15, $\gamma$-chlordan; 16, endosulfan I; $17 \alpha$-chlordane; 18, dieldrin; 19, p, p'-DDE; 20, endrin; 21, nitrofen; 22, endosulfan II; 23, $p, p^{\prime}$-DDD; 24, o, $p^{\prime}$-DDT; 25, endrin aldehyde; 26, endosulfan sulphate; 27, $p, p^{\prime}$-DDT; 28, methoxychlor; 29, cypermethrin; 30, fenvalerate; 31 , deltamethrin; 32, OCPs; 33, total pesticides).

for cypermethrin, trifluralin, methoxychlor, metolachlor, heptachlor, endosulfan I, $\alpha$-chlordane, endrin aldehyde, endosulfan sulphate and deltamethrin though there were low concentrations of $\gamma-\mathrm{HCH}$ and heptachlor, $\alpha$-chlordane, endrin aldehyde in the reservoir. However, though high fluxes of $\beta-\mathrm{HCH}, \delta-\mathrm{HCH}$, aldrin, $p, p^{\prime}$-DDE, $o, p^{\prime}$-DDT and $p, p^{\prime}$-DDT were found, low flux composition (\%) in surface water were found. The difference of flux composition for pesticides in sediment, pore water and surface water may be mainly caused from different pesticide's properties such as degradation, migration and adsorption of pesticides in environmental media. The values of octanol-water partition coefficient $\left(K_{\mathrm{ow}}\right)$ and sediment-pore water equilibrium partitioning coefficient $\left(K_{\mathrm{oc}}\right)$, the main parameters of degradation, migration and adsorption of pesticides, play an important role in distribution of pesticides in water body (Khim et al., 2001). The flux composition were 92.8\% in sediment, $5.0 \%$ in pore water and $2.2 \%$ in surface water, respectively, for total OCPs and $91.6 \%$ in sediment, $6.0 \%$ in pore water and $2.4 \%$ in surface water, respectively for total 31 pesticides. Therefore, sediments, as a sink of most pesticides, are the potential pesticide sources of surface water. The degree of sediment-water partitioning of a substance therefore plays a key role in the development of sediment quality criteria (Frank et al., 2003). It was possible to examine the relationship between sediment and water flux of pesticides. The flux of pesticides between water and sediment, water and pour water were calculated when predicting the degree of sediment-water partitioning in order to estimate environmental distribution and fate of the contaminants.
Sediment- water partition coefficient $\left(K_{\mathrm{sw}}\right)$ was derived as

$K_{\mathrm{sw}}=C_{\mathrm{s}} / C_{\mathrm{w}}$

where $C_{\mathrm{s}}$ is the flux in sediment, $C_{\mathrm{w}}$ is the flux in water. $K_{\text {sw }}$ can be therefore calculated though the values $C_{\mathrm{s}}$ and $C_{\mathrm{w}}$. for each individual pesticide in Guanting reservoir. The results showed that values of $K_{\mathrm{sw}}$ vary with different pesticides and different sampling sites. There are higher $K_{\text {sw }}$ values for some pesticides such as $\delta-\mathrm{HCH}$ (847) and endosulfan II (275), and there are lower $K_{\text {sw }}$ values for other pesticides such as cypermethrin (2.8), metolachlor (3.3) and $\gamma-\mathrm{HCH}$ (3.3). The larger discrepancy of values are possibly correlated with some factors such as different physicochemical characteristics of individual pesticide, the current status of individual pesticide used and different organic matter content in sampling sites.

Among all sampling sites, there were the higher pesticide level in site 1 , site 5 , site 6 , site 7 than others in Guanting reservoir whether in water, pore water or in sediment. The data from water samples are in agreement with the results about $\mathrm{HCH}$ and DDT in Guanting reservoir from Wang et al. (2000). Considering to higher values of organic matter (LOI, \%), Clay (\%) plus Silt $(\%)$ in site 1 , site 2 , site 6 , site 7 than in other sites, we can conclude that pesticides in the reservoir sediment are correlated with some factors such as organic matter LOI (\%), Clay (\%) and silt (\%). Particularly organic matter, which influences microbial activities and variation, plays a most important role in accumulation, enrichment or degradation to pesticides. It may be due to 
the fact that organic hydrophobic pollutants tend to stay in the sediments.

\section{Summary}

A method based on a pesticide multi-residue analysis to screen potential or suspected endocrine-disrupting pesticides in water and sediment was developed. The analyzed samples showed the presence of 31 pesticides in water and sediments from Beijing Guanting reservoir. The concentrations of pesticides in water are generally lower than the Chinese standards (in the grade 1-3 surface water) for surface water. However, values in a few sites are considerately high considering to being used as a drinking water source. Due to the analytical restrictions, ionic and thermally unstable pesticides could not be covered by our monitoring study, although some of them were also frequently used in the study area and they were also identified as potential or suspected endocrine disruptors such as atrazine, 2,4-D, diazinon, malathion (Dutta et al., 1993; Crain and Guillette, 1998; Ren and Jiang, 2001; Laura and Dutta, 2005). Further monitoring method study, which can screen more endocrinedisrupting pesticides, is also needed to understand and assess fully the contamination status about endocrinedisrupting pesticides in the studied area.

Pesticides were expected to be caused from several pathways such as contaminants through the rivers and drainage of contaminated water from the surrounding agricultural fields into Guanting reservoir, the diffusion of contaminants in sediment through the pores, agricultural operations. The concentration of pesticides in sediment was higher than those in surface water. It may be due to the fact that organic hydrophobic pollutants tend to stay in the sediments. And considering to higher values of pesticides in the sites with higher values of organic matter (LOI, \%), we can conclude that organic matter, which influences microbial activities and variation, play a most important role in accumulation, enrichment or degradation to pesticides.

Among the analyzed pesticides, $p, p^{\prime}$-DDE, $o, p^{\prime}-$ DDT, $\beta-\mathrm{HCH}, \gamma-\mathrm{HCH}$, endosulfan sulfate, aldrin were the most abundant pesticides in water while $o, p^{\prime}$-DDT, $\delta$ - $\mathrm{HCH}, \beta-\mathrm{HCH}, p, p^{\prime}$-DDE, $p, p^{\prime}$-DDT, endosulfan sulfate were the most abundant in sediment. These results underscore the need to improved environmental protection measures in order to reduce the exposure of the population and aquatic biota to these endocrine-disrupting compounds. And the abundant current use of the pesticides in the area and the river watersheds should be minimized. Furthermore, regular monitoring is needed to evolve a strategy to manage the environmental hazards due to these pesticides. Further measures, such as dredging sediment, need be taken for using as a municipal water supply source.

\section{Acknowledgements}

This study was financially supported by Ministry of Sciences and Technology, China (2003CB415005). The authors wish to thank Mr. Zhe Cao from Agilent Technologies, Beijing Environment Laboratory for helping with mass spectrometric confirmations. The authors also to thank to Dr. Xue-tong Wang and Dr. Yang-Zhao Sun for the help of sampling site.

\section{References}

Bakan, G., Ariman, S., 2004. Persistent organochlorine residues in sediments along the coast of mid-Black Sea region of Turkey. Mar. Pollut. Bull. 48, 1031-1039.

Bakan, G., Kaya, S., Ozkoc, H.B., Kurt, P., 1999. Certain organic pollutant levels in surface sediment of the mid Black Sea coast of Turkey. MEDCOAST' 99, Antalya, Turkey, pp. 455-464.

Castilho, J.A., Fenzl, N., Guillen, S.M., Nascimento, F.S., 2000. Organochlorine and organophosphorus pesticide residues in the Atoya river basin, Chinandega, Nicaragua. Environ. Pollut. 110, 523-533.

Castillo, L.E., Ruepert, C., Solis, E., 2000. Pesticide residues in the aquatic environment of banana plantation areas in the North Atlantic Zone of Costa Rica. Environ. Toxicol. Chem. 19, 1942-1950.

Chau, A.S.Y., Afgan, B.K., 1982. Analysis of Pesticides in Water, vol. 1: Significance, Principles, Techniques and Chemistry of Pesticides, vol. 2: Chlorine and Phosphoruscontaining Pesticides. CRC Press Inc., Boca Raton, FL, 91113-238.

Chen, W.Q., Zhang, L.P., Xu, L., Wang, X.H., Hong, H., 1996. Concentrations and distributions of HCHs, DDTs and PCBs in surface sediments of sea area between Xiamen and Jinmen. Journal of University (Natural Science) (in Chinese) 35, 936-940.

Colborn, T., Dumanoski, D., Myers, J.P., 1996. Our Stolen Future: are We Threatening Our Fertility, Intelligence, and Surival? Scientific Detective Story. Dutton Books, New York, p. 3.

Colborn, T., Smolen, M.J., 1996. Epidemiological analysis of persistent organochlorine contaminations in cetaceans. Rev. Environ. Contam. Toxicol. 146, 91-172.

Crain, D., Guillette, L., 1998. Reptilesas models of contaminant-induced endocrine disruption. Animal Reprod. Sci. 53 (1-4), 78-86.

Doong, R.A., Sun, Y.C., Liao, P.L., Peng, C.K., Wu, S.C., 2002. Distribution and fate of organochlorine pesticide residues in sediments from the selected rivers in Taiwan. Chemosphere 48, 237-246.

Dutta, H.M., Adihikai, S., Singh, N.K., Roy, P.K., Munshi, J.S.D., 1993. Histopathological changes induced by malathion in the liver of a freshwater catfish, Heteropneustis fossilis. Bull. Environ. Contam. Toxicol. 51, 895-900.

ENDS, 1999, Industry glimpses new challenges as endocrine science advances. ENDS Report 290, pp. 26-30.

Fernandez, M.A., Alonso, C., Gonzalez, M.J., Hernandez, L.M., 1999. Occurrence of organochlorine insecticides, 
PCBs, and PCB congeners in waters and sediments of the Ebro River (Spain). Chemosphere 38 (1), 33-43.

Fillmann, G., Readman, J.W., Tolosa, I., Bartocci, J., Villeneuve, J.P., Cattini, C., Mee, L.D., 2002. Persistent organochlorine residues in sediments from Black Sea. Mar. Pollut. Bull. 44, 122-133.

Frank, A., Gobas, P.C., Maclean, L.G., 2003. Sediment-water distribution of organic contaminants in aquatic ecosystems: the role of organic carbon mineralization. Environ. Sci. Technol. 37, 35-741.

Galehouse, J.S., 1971. Sedimentation analysis. In: Carver, R.E. (Ed.), Procedures in Sedimentary Petrology. Wiley-Interscience, New York, pp. 69-92 (Chapter 4).

Golterman, H.L., Sly, P.G., Thomas, R.L., 1983. Study on the realtionship between water quality and sediment transport. UNESCO, Technical Papers in Hydrology 26, France.

Hakanson, L., Jansson, M., 1983. Principles of Lake Sedimentology. Springer-Verlag, New York.

Hileman, B., 1994. Reproductive estrogens linked to reproductive abnormalities cancer. Chem. Eng. News (31 January), $19-20$.

Hong, H., Xu, L., Zhang, L.P., Chen, J.C., Wong, Y.S.M., 1995. Environmental fate and chemistry of organic pollutants in the sediments of Xiamen and Victoria Harbours. Mar. Pollut. Bull. 31, 229-236.

Hong, H., Chen, W., Xu, L., Wang, Z., Zhang, L., 1999. Distribution and fate of organochlorine pollutants in the Pearl River Estuary. Mar. Pollut. Bull. 39, 376-382.

Iwata, H., Tanabe, S., Sakai, N., Nishimura, A., Tatsukawa, R., 1994a. Geographical distributions of persistent organochlorines in air, water and sediments from Asia and Oceania and their implications for global redistribution from low latitudes. Environ. Pollut. 85, 15-33.

Iwata, H., Tanabe, S., Aramoto, M., Sakai, N., Tatsukawa, R., 1994b. Persistent organochlorine residues in sediments from the Chukchi Sea, Bering Sea and Gulf of Alaska. Mar. Pollut. Bull. 28, 746-753.

Kelce, W.R., Stone, C.R., Law, S.C., Gray, L.E., Kemppainen, J.A., Wilson, E.M., 1995. Persistent DDT metabolite $p, p^{\prime}$ DDE is a potent androgen receptor antagonist. Nature 375 , 581-585.

Khan, M.A.Q., 1977. Pesticides in Aquatic Environment. Plenum Press, New York.

Khim, J.S., Kannan, K., Villeneuve, D.L., Kon, C.H., Giesy, J.P., 1999. Characterization and distribution of trace organic contaminants in sediment from Masan Bay, Korea. 1. Instrumental analysis. Environ. Sci. Technol. 33, 41994205.

Khim, J.S., Lee, K.T., Kannan, K., Villeneuve, D.L., Giesy, J.P., Koh, C.H., 2001. Trace organic contaminants in sediment and water from Ulsan Bay and its vicinity, Korea. Arch. Environ. Contam. Toxicol. 40, 141-150.

Laura, B.M., Dutta, H.M., 2005. Diazinon-induced endocrine disruption in bluegill sunfish, Lepomis Macrochirus. Ecotoxicol. Environ. Safety 60, 21-27.

Li, Y.F., Cai, D.J., Shan, Z.J., Zhu, Z.L., 2001. Gridded usage inventories of technical hexachlorocyclohexane and lindane for China with $1 / 6$ latitude by $1 / 4$ longitude resolution. Arch. Environ. Contam. Toxicol. 41, 261-266.

Liu, M., Yang, Y., Hou, L., Xu, S., Ou, D., Zhang, B., Liu, Q., 2003. Chlorinated organic contaminants in surface sedi- ments from the Yangtze Estuary and nearby coastal areas, China. Baseline/Mar. Pollut. Bull. 46, 659-676.

Mac Doanld, D.D.A., 1994. Review of Environmental Quality Criteria and Guidelines for Priority Substances in the Fraser River Basin. Mac Donald Environmental Science Limited, Environmental Conservation Branch, Canada.

Monirith, I., Ueno, D., Takahashi, S., Nakata, H., Sudaryanto, A., Subramanian, A., Karuppiah, S., Ismail, A., Muchtar, M., Zheng, J., Richardson, B.J., Prudente, M., Hue, N.D., Tana, T.S., Tkalin, A.V., Tanabe, S., 2003. Asia-Pacific mussel watch: monitoring contamination of persistent organochlorine compounds in coastal waters of Asian countries. Mar. Pollut. Bullet. 46, 281-300.

Nakata, H., Hirakawa, Y., Kawazoe, M., Nakabo, T., Arizono, K., Abe, S., Kitano, T., Shimada, H., Watanabe, I., Li, W., Ding, X., 2005. Concentrations and composition of organochlorine contaminants in sediments, soils, crustaceans, fishes, and birds collected from Lake Tai, Hangzhou Bay, and Shanghai city region, China. Environ. Pollut. 133, 415429.

Nakata, H., Kawazoe, M., Arizono, K., Abe, S., Kitano, T., Shimada, M., Li, W., Ding, X., 2002. Organochlorine pesticides and polychlorinated biphenyl residues in foodstuffs and human tissues from China: Status of contamination, historical trend and human dietary exposure. Arch. Environ.Contam. Toxicol. 43, 473-480.

Nhan, D.D., Am, N.M., Carvalho, F.P., Vieneuve, J.P., Cattini, C., 1999. Organochlorine pesticides and PCBs along the coast of north Vietnam. Sci. Total Environ. 237/ 238, 363-371.

Nogueira, J.M.F., Sandra, T., Sandra, P., 2004. Multiresidue screening of neutral pesticides in water samples by high performance liquid chromatography-electrospray mass spectrometry. Anal. Chim. Acta 502 (2), 209-215.

Qiu, X., Zhu, T., Li, J., Pan, H., Li, Q., Miao, G., Hong, J., 2004. Organochlorine pesticides in the air around the Taifu Lake, China. Environ. Sci. Technol. 38, 1368-1374.

Ren, J., Jiang, K., 2001. Progress in research of endocrine disrupting chemicals. Prog. Chem. 13, 135-144.

Richardson, B.J., Zheng, G.J., 1999. Chlorinated hydrocarbon contaminants in Hong Kong surficial sediments. Chemosphere 39, 913-923.

Sarkar, A., Sen Gupta, R., 1991. Pesticide residues in sediments from the west coast of India. Mar. Pollut. Bull. 22, 42-45.

SEPA (State Environmental Protection Administration of China), 1999. Environmental quality standard for surface water (GHZB1-1999).

Tanabe, S., Iwata, H., Tatsukawa, R., 1994. Global contamination by persistent organochlorines and their ecotoxicological impact on marine mammals. Sci. Total Environ. 154, 163-177.

Turusov, V., Rakitsky, V., Tomatis, L., 2002. Dichlorodiphenyltrichloroethane (DDT): ubiquity, persistence, and risks. Environ. Health Perspect. 110 (2), 125-128.

US EPA, 1998. Endorine Disruptor Screening and Testing Advisor Committee (EDSTAC) Final Report.

USEPA, Environmental Fate and Effects Division Office of Pesticide Programs (OPPs), 1999. Sediment toxicity and fate of synthetic pyrethroids. Review of studies on partitioning, toxicity, and bioavailability of synthetic pyrethroids in 
sediments. January 25, 1999, US Environmental Protection Agency, Washington, DC.

Volker, L., Wulf, A., Pinto, A.A., Wantzen, M., da Silva, C.J., Zech, W., 2002. Pesticides in surface water, sediment, and rainfall of the northeastern Pantanal Basin, Brazil. J. Environ. Qual. 31 (5), 1636-1648.

Wang, X.T., Chu, S.G., Xu, X.B., 2000. Organochlorine pesticide residues in water from Guanting reservoir and Yongding river, China. Bull. Environ. Contam. Toxicol. 70, 351-358.

Wade, T.L., Velinsky, D.J., Reinharz, E., Schlekat, C.E., 1994. Tidal river sediments in the Washington, DC area. II. Distribution and sources of organic contaminants. Estuaries 27, 321-333.

Wu, Y., Zhang, J., Zhou, Q., 1999. Persistent organochlorine residues in sediments from Chinese river/estarine systems. Environ. Pollut. 105, 143-150.

Zhang, G., Parker, A., House, A., Mai, B., Li, X., Kang, Y., Wang, Z., 2002a. Sedimentary records of DDT and HCH in the Pearl River Delta, South China. Environ. Sci. Technol. 36, 3671-3677.

Zhang, Z.L., Hong, H.S., Zhou, J.L., Yu, G., Chen, W.Q., Wang, X.H., 2002b. Transport and fate of organochlorine pesticides in River Wuchuan, Southeast China. J. Environ. Monitor. 4 (3), 435-441.
Zhang, Z.L., Dai, M.H., Hong, H.S., Zhou, J.L., Yu, G. 2002c. Dissolved insecticides and polychlorinated biphenyls in the Pearl River Estuary and South China Sea. J. Environ. Monitor. 4 (6), 922-928.

Zhang, Z.L., Hong, H.S., Wang, X.H., Lin, J.Q., Chen, W.Q., $\mathrm{Xu}, \mathrm{L} ., 2$ 2002d. Determination and load of organophosphorus and organochlorine pesticides at water from Jiulong River Estuary, China. Mar. Pollut. Bull. 45 (1-12), 397-402.

Zhang, Z.L., Hong, H.S., Zhou, J.L., Huang, J., Yu, G., 2003. Fate and assessment of persistent organic pollutants in water and sediment from Minjiang River Estuary, Southeast China. Chemosphere 52 (2003), 1423-1430.

Zhang, Z., Huang, J., Yu, G., Hong, H., 2004. Occurrence of PAHs, PCBs and organochlorine pesticides in the Tonghui River of Beijing, China. Environ. Pollut. 130, 249-261.

Zhou, J.L., Hong, H.S., Maskaoui, K., Chen, W., 2000. Multiphase distribution of organic micropollutants in Xiamen Harbour, China. Water Res. 34, 2132-2215.

Zhou, J.L., Maskaoui, K., Qiu, Y.W., Hong, H.S., Wang, Z.D., 2001. Polychlorinated biphenyl congeners and organochlorine insecticides in the water column and sediments of Daya Bay, China. Environ. Pollut. 113, 373-384.

Zhou, J., Qin, Z., Cong, L., Xu, X., 2004. Research progress of the endocrine disrupting activities of polychlorinated biphenyls. Chinese Sci. Bull. 49 (3), 215-219. 